DOI: $10.2478 / \mathrm{rrlm}-2014-0010$

\title{
Blastic plasmacytoid dendritic cell neoplasia - a rare type of acute leukemia
}

\author{
Neoplasm cu celule dendritice plasmocitoide blastice - o formă \\ rară de leucemie acută
}

\author{
Judit Beáta Köpeczi ${ }^{1}$, Erzsébet Benedek ${ }^{1 *}$, Enikő Kakucs ${ }^{1}$, Aliz Tunyogi ${ }^{1}$, \\ Monica Istrati ${ }^{1}$, Istvan Benedek ${ }^{1,2}$ \\ 1. Clinical Hematology and Bone Marrow Transplantation Clinic, Tîrgu-Mureş \\ 2. University of Medicine and Pharmacy, Tîrgu-Mureş
}

\begin{abstract}
Blastic plasmacytoid dendritic cell neoplasm (BPDCN), recently classified among the acute myeloid leukemia and related precursor neoplasms, is a rare hematological malignancy with highly aggressive clinical course.

We report a case of a 55 year-old female patient who presented spontaneous rupture of the spleen. The histopathological diagnosis without immunohistochemistry was splenic marginal zone non-Hodgkin lymphoma (NHL). The patient received 4 courses of polychemotherapy. Due to the unfavorable evolution the spleen was histopathologically reexamined and immunohistochemistry was performed in another laboratory. The diagnosis of NHL was excluded. Undifferentiated malignant cell proliferation, possible myeloid was suspected. Due to the discrepancy between diagnoses, a third immunohistological examination was performed in a third laboratory. NHL was excluded and myeloid, NK-cell or plasmacytoid dendritic cell leukemia was suspected. The patient was admitted to our clinic after 8 months from the initial diagnosis. Immunophenotyping by flowcytometry from the bone marrow showed 23\% blasts positive for CD4, CD56, CD123, HLA-DR, CD38, CD11b, CD2, and negative for lineage specific markers of B-, T-lymphoid, NK- or myelomonocytic cells. The final diagnosis was BPDCN in leukemic phase.

Due to the diversity of the clinical presentation, morphology and immunophenotype of BPDCN the diagnosis of this rare malignancy remains challenging. Immunophenotyping by flowcytometry is superior to immunohistochemistry because of the availability of a larger panel of antibodies and the possibility to identify the intensity of antigen expression. The atypical forms of BPDCN should be recognized early in order to manage properly the patients with this aggressive disease.
\end{abstract}

Key words: blastic plasmacytoid dendritic cell neoplasm, CD4+/CD56+/lin-neoplasm, immunophenotyping, CD123

*Corresponding author: Erzsébet Benedek, Clinical Hematology and Bone Marrow Transplantation Clinic, Tîrgu-Mureş, phone: 0265-218739, e-mail: dr_benedek@yahoo.com 


\section{Rezumat}

Neoplasmul cu celule dendritice plasmocitoide blastice (NCDPB), clasificat recent în grupul leucemiilor acute mieloide este o boală hematologică malignă rară cu evoluţie clinică extrem de agresivă.

Raportăm cazul unei paciente în vârstă de 55 ani care a prezentat ruptură spontană a splinei. Diagnosticul histopatologic, fără imunohistochimie, a fost de limfom malign non-Hodgkin (LMNH) splenic de zonă marginală. Pacienta a primit 4 cure citostatice. Datorită evoluţiei nefavorabile, splina a fost reexaminată histopatologic şi imunohistochimic într-un alt laborator. Diagnosticul de LMNH a fost exclus şi s-a ridicat suspiciunea unei proliferări maligne, posibil mieloide. Datorită neconcordanţei dintre diagnostice s-a efectuat o nouă examinare imunohistochimică într-un al treilea laborator. LMNH se infirmă şi se suspicionează leucemie mieloidă, cu celule NK sau cu celule dendritice plasmocitoide. Pacienta a fost internată în clinica noastră după 8 luni de la diagnosticul iniţial. Imunofenotiparea prin citometrie în flux efectuată din măduva osoasă a evidenţiat $23 \%$ blaşti pozitivi pentru markerii CD4, CD56, CD123, HLA-DR, CD38, CD11b, CD2 şi negativi pentru markerii specifici liniilor celulare limfoide B, T, NK şi mielomonocitare. Diagnosticul final a fost NCDPB în fază leucemică.

Datorită diversităii prezentării clinice, morfologice şi imunofenotipice a NCDPB, diagnosticul acestei boli maligne rare rămâne o provocare. Imunofenotiparea prin citometrie în flux este superioară examenului imunohistochimic datorită disponibilităţii unui panel mai larg de anticorpi şi posibilităţii de a identifica intensitatea expresiei antigenice. Formele atipice ale NCDPB trebuie să fie recunoscute în timp util pentru a putea trata corespunzător pacienţii cu această boală agresivă.

Cuvinte cheie: neoplasm cu celule dendritice plasmocitoide blastice, neoplasm CD4+/CD56+/lin-, imunofenotipare, $C D 123$

\section{Received: 14 ${ }^{\text {th }}$ June 2013; Accepted: $5^{\text {th }}$ February 2014; Published: $11^{\text {th }}$ March 2014.}

\section{Introduction}

Blastic plasmacytoid dendritic cell neoplasm $(\mathrm{BPDCN})$ is a rare type of hematological neoplasm that was included in 2008 by WHO (World Health Organization) classification among the acute myeloid leukemia and related myeloid neoplasms (1).

Due to the uncertain ontogenetic origin this entity has been defined with many different terms, such as CD4+/CD56+ agranular cutaneous lymphoma or CD4+/CD56+ hematodermia, blastic NK-cell leukemia/lymphoma, CD4+/ CD56+ hematodermic neoplasm or early plasmacytoid dendritic cell leukemia/lymphoma (2). In $2008 \mathrm{WHO}$ introduced the term of blastic plasmacytoid dendritic cell neoplasm (BPDCN) (1). The plasmacytoid dendritic cell origin was suggested first by Lucio et al (3). This hematological neoplasm has been shown as a malignant counterpart of plasmacytoid dendritic cell (pDC) (4).
This disease mainly affects older adults but pediatric cases have also been described (5). It has a male/female ratio of 3-3.5:1 $(6,7)$.

In the majority of patients the first clinical manifestations are the isolated or multiple cutaneous lesions that can be plaques, papules, bruise-like areas or subcutaneous nodules. Bone marrow and peripheral blood involvement can be absent or minimal at the diagnosis but develops in a few months with progression of diseases. The other patients present with disseminated disease showing characteristics of an acute leukemia with bone marrow and peripheral blood involvement from the beginning. Also in these cases the skin lesions are frequently present (69). Lymph nodes and other areas such as spleen, liver, tonsils, mucosa-associated lymphoid tissues, lungs, kidneys, muscles, central nervous system are often invaded (2,8). Cytopenia, especially thrombocytopenia, are common at diagnosis $(2,6,10)$. The malignant cells show immature blastic features that morphologically present a 
great variability $(10,11)$. Histopatologically the cutaneous lesions show a mononuclear cell infiltration into the dermis sparing the epidermis and without angiotropism $(6,12)$.

BPDCN is characterized by the following immunophenotype: $\mathrm{CD} 4+, \mathrm{CD} 56+$, lineage negative (intracytoplasmic MPO-, CD3-, CD79a), CD45RA+/RO-, CD11c-, CD116+ low, CD123+, CD36+, HLA-DR+, CD34-, CD45 low (13). However, the immunophenotype of the tumor cells can be very heterogeneous and often does not correspond exactly with the mentioned antigen profile (11). In these cases other pDC specific antigens are useful for diagnosis: BDCA-2 (CD303), TCL-1, CLA (cutaneous lymphocyte associated antigen) $(11,13)$.

The clinical course of disease is very aggressive. Despite of initial good response to the multiagent chemotherapy early and widespread relapses occur in the majority of the patients with a median survival of $12-14$ months $(6,8,14)$. Different therapeutic approaches were described in the literature but there is no consensus for optimal treatment $(10,14)$. Longer survival was reported only in younger patients treated with acute leukemia induction therapy followed by allogeneic stem cell transplantation performed in first complete remission (14-16).

\section{Case report}

We report a case of a 55 year-old female patient who presented spontaneous rupture of the spleen. She had a history of 2-months asthenia and progressive jaundice. The blood count revealed normal white blood cell count (WBC), neutropenia, monocytosis, anemia and thrombocytopenia: WBC: $6.95 \times 10^{9} / 1$, Neutrophils: 1.9 x10\%/1, (27\%), Monocyte: $2.92 \times 10^{9} / 1$, (41\%), Hemoglobin (Hgb): $6.82 \mathrm{~g} / \mathrm{dl}$, Platelets (Plt): $43.7 \times 10^{9} / 1$. The routine laboratory tests disclosed abnormal liver function: AST (aspartate amino transferase): $88 \mathrm{U} / 1$, ALT (alanine amino trans- ferase): $422 \mathrm{U} / 1$, total bilirubin: $6.7 \mathrm{mg} / 1$, direct bilirubin: $2.9 \mathrm{mg} / 1$, indirect bilirubin: $3.8 \mathrm{mg} / \mathrm{l}$.

Computed tomography scans showed interruption of the continuity of splenic capsule, perisplenic effusion, peritoneal fluid, splenomegaly, hepatomegaly and retroperitoneal lymphadenopathy. The spleen was surgically removed. The histopathological examination without immunohistochemistry - described diffuse proliferation with small and medium-sized atypical lymphocytes with incised nuclei and small nucleoli and diagnosis of marginal zone splenic non-Hodgkin lymphoma (NHL) was established. The histopathological analysis of the bone marrow (BM) biopsy showed interstitial infiltration with atypical lymphocytes characterized by irregular nuclei with inconspicuous nucleoli suggesting the lymphomatous involvement of the BM. Immunophenotyping by flowcytometry from the bone marrow wasn't performed.

The patient received 2 courses of CHOP (Cyclophosphamide, Hydroxidaunorubicine, Vincristine, Prednisolone) chemotherapy and 2 courses of R-CHOP (Rituximab, Cyclophosphamide, Hydroxidaunorubicine, Vincristine, Prednisolone). After the initiation of chemotherapy the laboratory data were normalized but the monocytosis persisted with values between $12-21 \%$ in the peripheral blood. Bone marrow biopsy was repeated after 4 courses of polychemotherapy (PCT). The histopathological analysis revealed $5-7 \%$ atypical medium-sized cells characterized by irregular nuclei with fine chromatin and inconspicuous nucleoli; the cytoplasm was basophilic and presenting membrane expansion concluding the presence of tumoral cells in the BM.

Due to the unfavorable evolution of the disease the spleen was histopathologically reexamined and immunohistochemistry was performed in another laboratory. The immunohistochemistry showed diffuse infiltration with medium-sized atypical cells in the red pulp and pre- 
sented negativity for the following tested antigens: CD20-, CD79a-, myeloperoxidase MPO-, CD34-, CD3-, CD5-. In conclusion, the diagnosis of NHL was excluded and undifferentiated malignant cell proliferation - possible myeloid - was suspected.

Due to the discrepancy between the first diagnosis: splenic marginal zone NHL and the second one: undifferentiated (myeloid) malignant cell proliferation, a third immunohistological examination was performed in a third laboratory. The histopathological reexamination of the spleen identified diffuse infiltration with medium-sized cells with blastic morphology. Immunostaining for CD20 was negative on these cells and the marginal zone NHL was excluded. The blastic cells were positive for CD45 and CD56 and negative for CD3, CD10, CD34 and c-kit. The bone marrow biopsy was also reexamined and showed interstitial infiltrate with CD3 negative and CD20 negative atypical cells. Residual hematopoietic tissue exhibited dysplastic features especially in megakaryocytes. The new histopathological result of the spleen excluded NHL and myeloid, NK-cell or plasmacytoid dendritic cell leukemia was suspected. The polychemotherapy was suspended.

The patient was admitted in our clinic with the mentioned medical history after 8 months from the initial diagnosis. She presented fatigue, nocturnal perspiration, erythematous skin lesion on the chest and hepatomegaly. The routine laboratory tests including biochemistry, renal function were within normal range except liver function with elevated value AST: $47 \mathrm{U} / 1$, ALT: $94 \mathrm{U} / \mathrm{l}$, GGT ( $\gamma$-glutamyl transferase): $151 \mathrm{U} / 1$, total bilirubin: $3.0 \mathrm{mg} / \mathrm{l}$, Direct Bilirubin: 0.87 $\mathrm{mg} / \mathrm{l}$. The antigen (Ag) and antibodies for B and $\mathrm{C}$ hepatitis and Epstein-Barr virus (EBV) were negative: $\mathrm{HBsAg}$, antiHBs, $\mathrm{HBeAg}$, antiHBe, antiHCV, antiEBV-IgM, antiEBV-IgG. The blood count showed normal WBC count, anemia and thrombocytopenia: WBC: $5.16 \times 10^{9} / 1$, Hgb: $9.5 \mathrm{~g} / \mathrm{dl}$, Plt: 80x10 $/ 1$. The bone marrow smear showed $23 \%$ blasts. Morphologically the blasts cells stained with May-Grünwald-Giemsa were pleomorphic with heterogeneous size. The nuclei were irregular or indented with fine to condensate chromatin and small nucleoli. The cytoplasm was slightly basophilic, non-granular with heterogeneous structure some of them presenting microvacuoles or pseudopodia-like membrane expansions (Figure 1).

Immunophenotyping by flowcytometry was performed. Whole bone marrow sample was stained using stain-lyse-and-then-wash direct immunofluorescence technique for surface markers and fix and permeabilization technique for in-

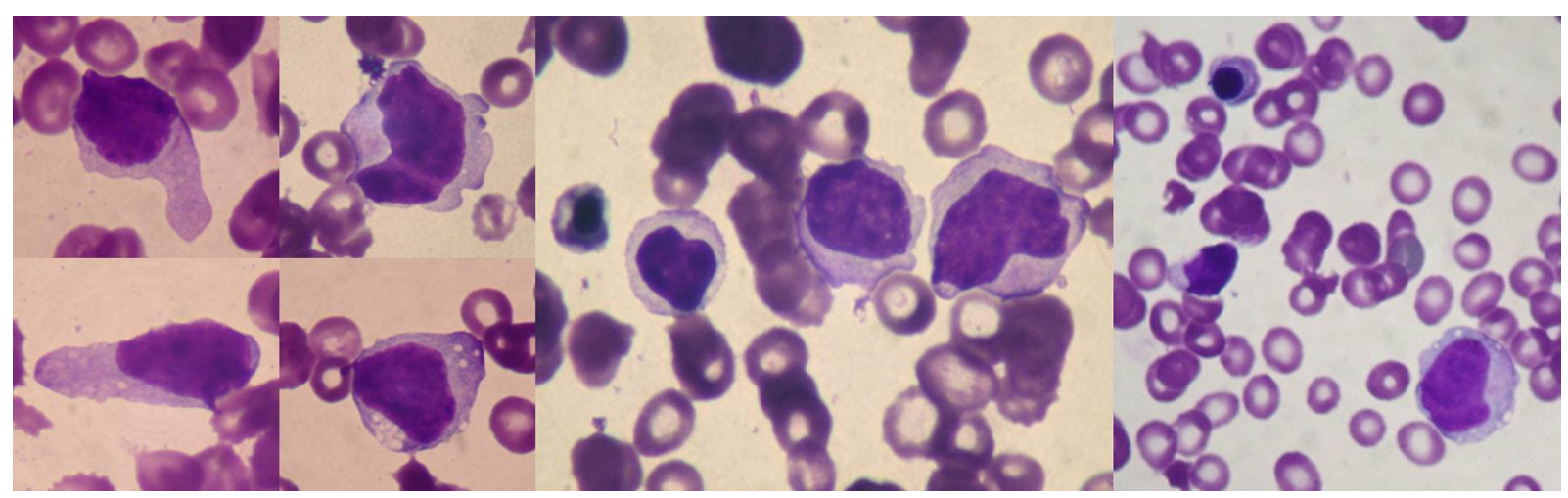

Figure 1. Morphology of the blasts stained with May-Grünwald-Giemsa (100x): pleomorphic with heterogeneous size. Nuclei irregular or indented with fine to condensate chromatin. Cytoplasmic microvacuoles, pseudopodia-like membrane expansion. 
tracellular markers. Data were acquired with FACSCalibur cytometer and analyzed with CellQUEST and Paint-a-Gate software. The blasts were positive for CD4, CD56, CD123, CD38, HLA-DR, CD11b (59\%), CD2 (54\%) and negative for following tested surface markers:
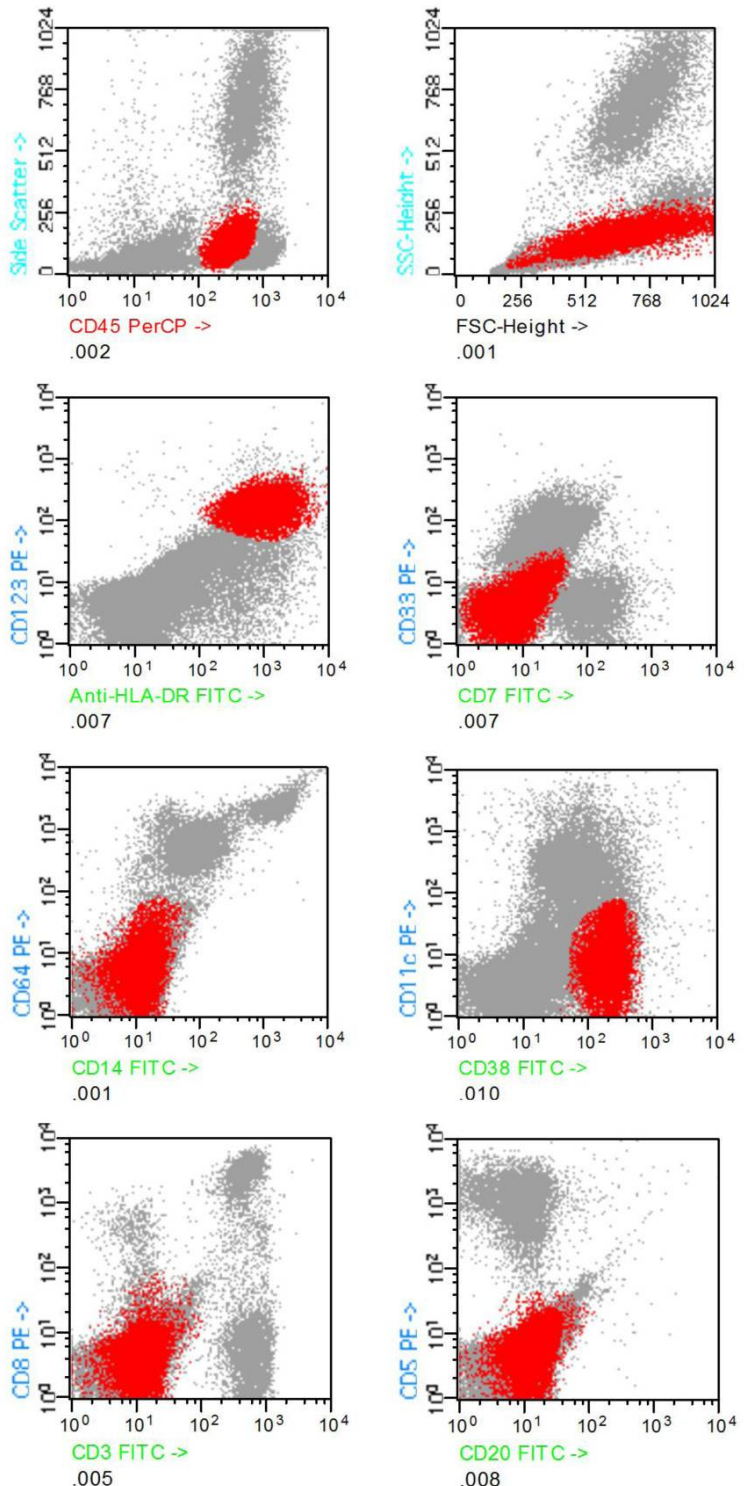

myelo-monocytic markers: CD13, CD33, CD15, CD64, CD14, CD16, CD36, CD11c, CD117, T-cell lineage markers: CD3, CD5, CD7, CD8, B-cell lineage markers: CD19, CD20, CD10, $\mathrm{CD} 22$, negative for CD34 (Figure 2) and were lineage negative (intracytoplasmic MPO-, CD3-,
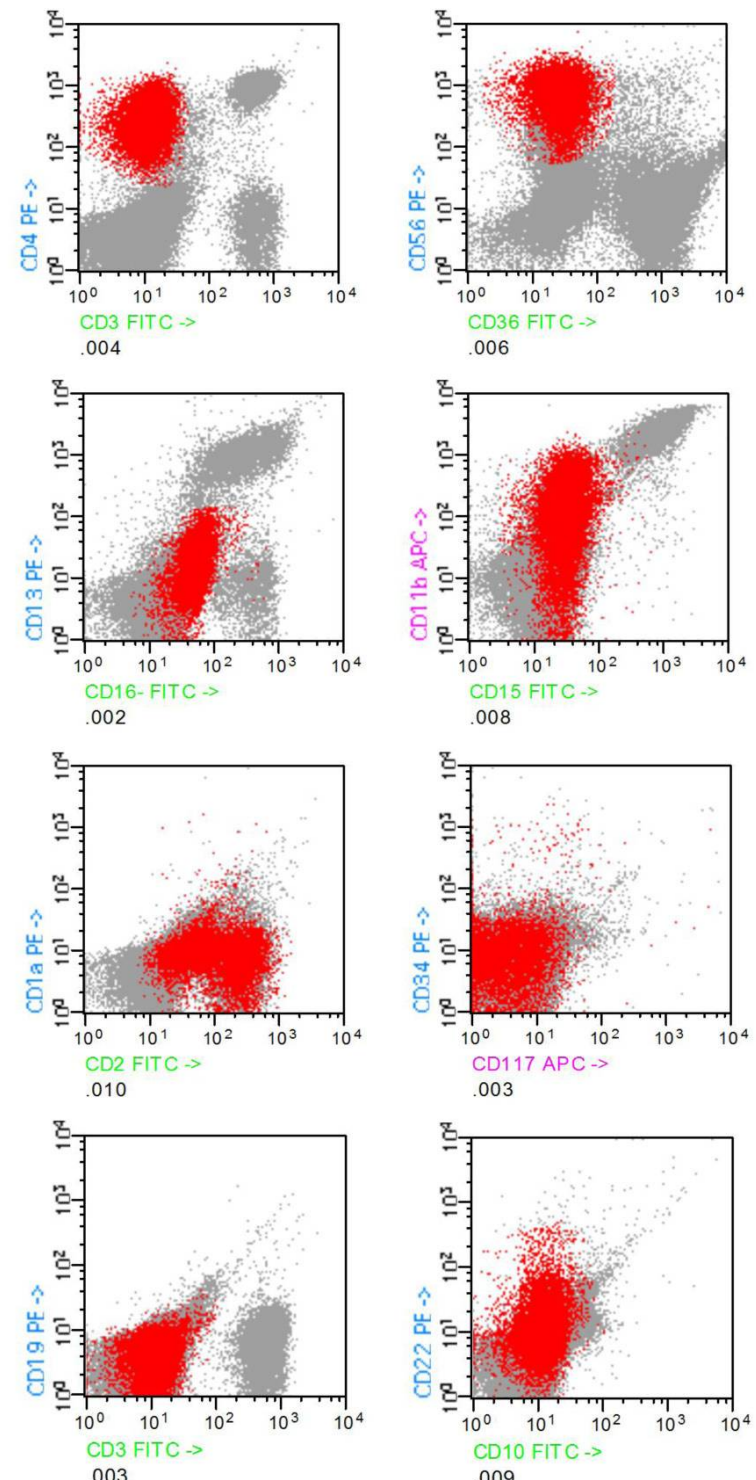

Figure 2. Immunophenotype of the blasts (red) detected by flowcytometry in the bone marrow sample (surface markers): positive for CD4, CD56, CD123, CD38, HLA-DR, CD11b (59\%), CD2 (54\%) and negative for myelo-monocytic markers: CD13, CD33, CD15, CD64, CD14, CD16, CD36, CD11c, CD117, T-cell lineage markers: CD3, CD5, CD7, CD8, B-cell lineage markers: CD19, CD20, CD10, CD22, negative for CD34. Data were analyzed with Paint-a-gate software. 

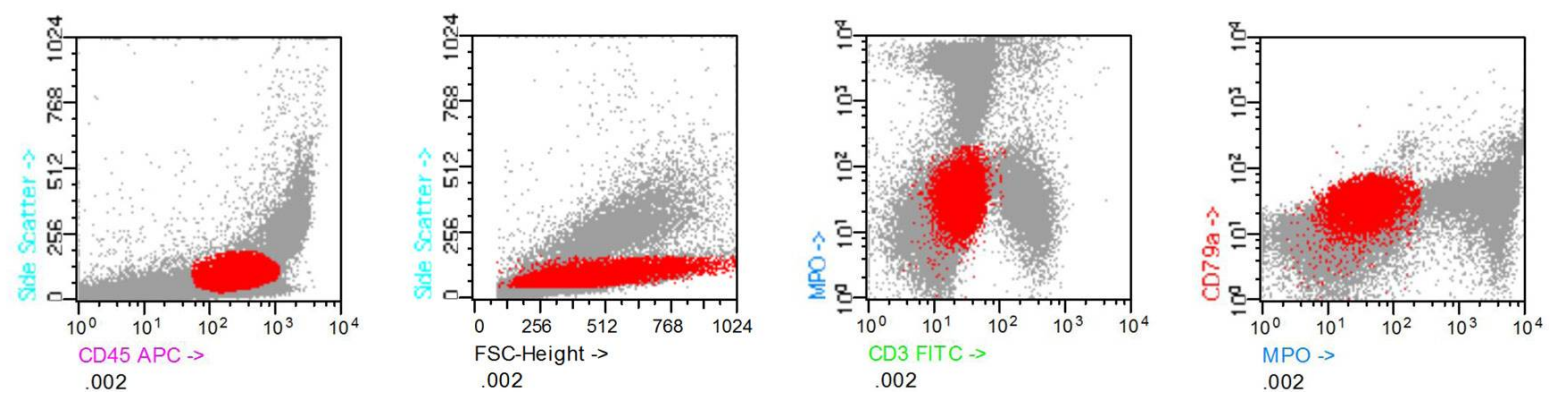

Figure 3. Immunophenotype of the blasts (red) detected by flowcytometry in the bone marrow sample (intracytoplasmic markers): the blasts are lineage negative: MPO-, CD3-, CD79a-. Data were analyzed with Paint-a-gate software.

CD79a-) (Figure 3). The final diagnosis was blastic plasmacytoid dendritic cell neoplasm in leukemic phase. Unfortunately the patient developed fulminant hepatitis and died in hepatic coma. Autopsy wasn't performed due to the request of the family.

\section{Discussion}

Blastic plasmacytoid dendritic cell neoplasm is a rare entity that occurs in less than $1 \%$ of all acute leukemias (8), in our laboratory from a total of 272 acute leukemias diagnosed by flowcytometry only 2 were identified as BPDCN $(0.73 \%)$.

In the majority of the cases the first clinical manifestations are the asymptomatic solitary or multifocal skin lesions (6-8). The particularity of this case was the unusual onset of disease, namely spontaneous rupture of the spleen. To our knowledge, spleen rupture has never been reported to be the first clinical manifestation. Erythematous skin lesions on the chest appeared after 7 months from the initial diagnosis.

The pleomorphic morphology and the immunophenotypic heterogeneity of the tumor cells may be the source of diagnostic pitfalls in BPDCN (11). In our case the incomplete histopathological analysis of the spleen and BM without immunohistochemistry and immunophenotyping was the principal source of the misdiag- nosis. The second and third histopathological examination with immunohistochemistry excluded the diagnosis of NHL, but the antibody panel used was still insufficient to make the correct diagnosis. The final diagnosis was established by immunophenotyping using a broad panel of monoclonal antibodies.

BPDCN was initially characterized by expression of $\mathrm{CD} 4+$ and $\mathrm{CD} 56+$ in the absence of lineage specific markers of B-, T-lymphoid, NK- or myelomonocytic cells. Garnache-Ottou confirmed that this profile is specific to BPDCN and wasn't described in any other form of acute leukemias (13). The diagnosis of BPDCN relies on the immunphenotype of the tumor cells: $\mathrm{CD} 4+, \mathrm{CD} 56+$, lineage negative (intracytoplasmic MPO-, CD3-, CD79a-), CD45RA+/RO-, CD11c-, CD116+ low, CD123 +, CD36+, HLADR+, CD34-, CD45 low (13). However, several studies reported cases that do not fit completely with this antigen profile or expressing different lineage antigens. Cota et al described cases with negativity of CD4, CD56, CD123, TCL-1 (11). Co-expression of CD33, CD7, CD2, CD117, CD22 was reported in several cases (17-19). In our patient, the immunophenotype of the blast cells from the BM aspirates show the antigen profile described for BPDCN except CD36 that was negative and CD11b and CD2 that were partially positive. 
The clinical differential diagnosis in this case includes: splenic B- or T-cell lymphomas, NK/T-lymphoma and acute myelo-monoblastc leukemia and lymphoblastic leukemia. B- and T-cell lymphomas were excluded both by immunohistochemistry and flowcytometry. All tested B-cell markers: CD19, CD20, CD10, CD22 and T-cell markers: CD3, CD5, CD7, CD8 were negative except $\mathrm{CD} 2$ that was partly positive (54\%). NK/T-lymphomas are differentiated by the presence of azurophilic granules in the cytoplasm and frequent association with EBV infection. Expression of CD56, CD7, CD2 can be common in NK/T-lymphoma and BPDCN but NK/T-lymphoma do not express CD4 (20). Some acute myeloblastic and lymphoblastic acute leukemias may express CD4 and CD56 (21) but another lineage specific surface and/or intracytoplasmic antigens should be expressed to confirm the diagnosis (22), so we excluded myeloblastic or lymphoblastic acute leukemia. Monoblastic and monocytic leukemia usually express CD4+ and CD11b+ together with markers characteristic of monocytic differentiation: CD64+, CD14+, CD11c+, CD36+. Aberrant expression of CD56+ is found in $25-40 \%$ of cases (1). CD14 is typical marker for monocytes but this marker is present only during the intermediate to last differential stages of monocytes. But CD64 is present during the earlier stages to last differential stages of monocytic maturation and this marker is required for identification of early monocytic cells (23). In our case monocytic lineage specific markers were not present and monoblastic acute leukemia was excluded. CD123 can be present in acute leukemia but the high expression of CD123 is a strong argument for pDC origin (13).

The optimal therapeutic approaches for BPDCN have not been established. CHOP chemotherapy protocol was described in several studies for treatment of BPDCN with a median survival of 12 months $(10,14)$. The evolution of the dis- ease was similar as described in literature $(7,9$, $10,15,16)$. Despite of good response to initial treatment early relapse occurred with aggressive progression of the disease and patient died due to fulminant hepatitis and hepatic coma after 9 month from the initiation of PCT.

\section{Conclusion}

The atypical onset of disease, the pleomorphic morphology of neoplastic cells, deficient histopathological analysis and insufficient antibodies available for immunohistochemistry were the sources of diagnostic pitfalls in this case.

Due to the diversity of the clinical presentation, morphology and immunophenotype of BPDCN the diagnosis of this rare form of hematological malignancy remains challenging. Immunopheotyping by flowcytometry is superior to immunohistochemistry because of the availability of a larger panel of antibodies and the possibility to identify the intensity of antigen expression.

The atypical forms of BPDCN should be recognized early in order to manage properly the patients with this aggressive hematological malignancy.

\section{Conflicts of interest}

The authors declare that there are no conflicts of interest concerning this paper.
Abbreviations
Ag - antigen
ALT - alanine amino transferase
AST - aspartate amino transferase
BDCA-2 - blood dendritic cell antigen 2
$\mathrm{BM}$ - bone marrow
BPDCN - blastic plasmacytoid dendritic cell neoplasm
CHOP - Cyclophosphamide, Hydroxidaunoru- bicine, Vincristine, Prednisolone 
CLA - cutaneous lymphocyte associated antigen

GGT- $\gamma$-glutamyl transferase

EBV - Epstein Barr Virus

$\mathrm{Hgb}$ - hemoglobin

NHL - non-Hodgkin lymphoma

$\mathrm{NK}$ - natural killer

pDC - plasmacytoid dendritic cell

Plt - platelets

R-CHOP - Rituximab, Cyclophosphamide, Hydroxidaunorubicine, Vincristine, Prednisolone

TCL-1 - T-cell leukemia/lymphoma 1

WBC - white blood cell

\section{References}

1. Facchetti F, Jones DM, Petrella T. Blastic plasmacytoid dendritic cell neoplasm in: Swerdlow SH, Campo E, Harris NL, Jaffe ES, Pileri SA, Stein H, et al. WHO Classification of Tumours of Haematopoietic and Lymphoid Tissues, 4th Edition. International Agency for Research on Cancer. Lyon 2008;145-7.

2. Garnache-Ottou F, Feuillard J, Saas P. Plasmacytoid dendritic cell leukaemia/lymphoma: towards a well defined entity? Br J Haematol. 2007;136(4):539-48. DOI: 10.1111/j.1365-2141.2006.06458.x

3. Lúcio P, Parreira A, Orfao A. CD123hi dendritic cell lymphoma: an unusual case of non-Hodgkin lymphoma. Ann Intern Med. 1999;131(7):549-50. DOI: 10.7326/0003-4819-131-7-199910050-00035

4. Chaperot L, Bendriss N, Manches O, Gressin R, Maynadie $\mathrm{M}$, Trimoreau F, et al. Identification of a leukemic counterpart of the plasmacytoid dendritic cells. Blood. 2001;97(10):3210-7. DOI: 10.1182/blood.V97.10.3210

5. Jegalian AG, Buxbaum NP, Facchetti F, Raffeld M, Pittaluga S, Wayne AS, et al. Blastic plasmocytoid dendritic cell neoplasm in children: diagnostic feature and clinical presentations. Haematologica. 2010;95(11):18739. DOI: $10.3324 /$ haematol.2010.026179

6. Herling M, Jones D. CD4+/CD56+ Hematodermic Tumor. The features of an evolving entity and its relationship to dendritic cells. Am J Clin Pathol. 2007;127(5):687-700. DOI: 10.1309/FY6PK436NBK0RYD4

7. Facchetti F, Ungari M, Marocolo D, Lonardi S, Vermi W. Blastic plasmocytoid dendritic cell neoplasm. Hematology Meeting Reports. 2009;3(3):1-3.

8. Jacob MC, Chaperot L, Mossuz P, Feuillard J, Valensi F, Leroux D, et al. CD4+ CD56+ lineage negative malignancies: a new entity developed from malignant early plasmacytoid dendritic cells. Haematologica. 2003;88(8):941-55.
9. Rauh MJ, Rahman F, Good D, Silverman J, Brennan MK, Dimov N, et al. Blastic plasmacytoid dendritic cell neoplasm with leukemic presentation, lacking cutaneous involvement: Case series and literature review. Leuk Res. 2012;36(1):81-6. DOI: 10.1016/j.leukres.2011.07.033

10. Feuillard J, Jacob MC, Valensi F, Maynadié M, Gressin R, Chaperot L, et al. Clinical and biologic features of CD4(+)CD56(+) malignancies. Blood. 2002;99(5):1556-63. DOI: 10.1182/blood.V99.5.1556

11. Cota C, Vale E, Viana I, Requena L, Ferrara G, Anemona $\mathrm{L}$, et al. Cutaneous manifestations of blastic plasmacytoid dendritic cell neoplasm-morphologic and phenotypic variability in a series of 33 patients. Am J Surg Pathol. 2010;34(1):75-87. DOI: 10.1097/PAS. 0b013e3181c5e26b

12. Petrella T, Bagot M, Willemze R, Beylot-Barry M, Vergier B, Delaunay $\mathrm{M}$, et al. Blastic NK-cell lymphomas (agranular CD4+CD56+ hematodermic neoplasms): a review. Am J Clin Pathol. 2005;123(5):662-75. DOI: 10.1309/GJWNPD8HU5MAJ837

13. Garnache-Ottou F, Feuillard J, Ferrand C, Biichle S, Trimoreau F, Seilles E, et al for GOELAMS and GEIL study. Extended diagnostic criteria for plasmacytoid dendritic cell leukaemia. Br J Haematol. 2009;145(5):62436. DOI: 10.1111/j.1365-2141.2009.07679.x

14. Pangano L, Valentini CG, Pulsoni A, Fisogni S, Carluccio P, Mannelli F, et al for GIMEMA-ALWP* (Gruppo Italiano Malattie EMatologiche dell'Adulto, Acute Leukemia Working Party). Blastic plasmacytoid dendritic cell neoplasm with leukemic presentation: an Italian multicenter study. Haematologica. 2013;98(2):23946. DOI: 10.3324/haematol.2012.072645

15. Reimer $P$, Rüdiger $T$, Kraemer D, Kunzmann V, Weissinger F, Zettl A, et al. What is CD4+CD56+ malignancy and how should it be treated? Bone Marrow Transplant. 2003;32(7):637-46. DOI: 10.1038/ sj.bmt. 1704215

16. Dietrich S, Andrulis M, Hegenbart U, Schmitt T, Bellos F, Martens UM, et al. Blastic plasmacytoid dendritic cell neoplasia (BPDC) in elderly patients: results of a treatment algorithm employing allogeneic stem cell transplantation with moderately reduced conditioning intensity. Biol Blood Marrow Transplant. 2011;17(8):1250-4. DOI: 10.1016/j.bbmt.2010.12.706

17. Garnache-Ottou F, Chaperot L, Biichle S, Ferrand C, Remy-Martin JP, Deconinck E, et al. Expression of the myeloid-associated marker CD33 is not an exclusive factor for leukemic plasmacytoid dendritic cells. Blood. 2005;105(3):1256-64. DOI: 10.1182/ blood-2004-06-2416

18. Bueno C, Almeida J, Lucio P, Marco J, Garcia R, de Pablos JM, et al. Incidence and characteristics of CD4(+)/HLA DRhi dendritic cell malignancies. Haematologica. 2004;89(1):58-69. 
19. Reineks EZ, Osei ES, Rosenberg A, Auletta J, Meyerson HJ. CD22 expression on blastic plasmacytoid dendritic cell neoplasms and reactivity of anti-CD22 antibodies to peripheral blood dendritic cells. Cytometry B Clin Cytom. 2009;76(4):237-48. DOI: 10.1002/ cyto.b. 20469

20. Suzuki R, Suzumiya J, Yamaguchi M, Nakamura S, Kameoka J, Kojima H,et al. NK-cell Tumor Study Group - Prognostic factors for mature natural killer (NK) cell neoplasms: aggressive NK cell leukemia and extranodal NK cell lymphoma, nasal type. Ann Oncol. 2010;21(5):1032-40. DOI: 10.1093/annonc/mdp418

21. Di Bona E, Sartori E, Zambello R, Guercini N, Medeo
D, Rodeghiero F. Prognostic significance of CD56 antigen expression in acute myeloid leukemia. Haematologica. 2002;87(3):250-6.

22. Béné MC. Biphenotypic, bilineal, ambiguous or mixed lineage: strange leukemias! Haematologica. 2009;94(7):891-3. DOI: 10.3324/haematol.2009.007799

23. Dongen JJM, Lhermitte L, Bottcher S, Almeida J, van der Velden VHJ, Flores-Montero J, et al. Euroflow antibody panels for standardized n-dimensional flowcytometric immunophenotyping of normal, reactive and malignant leukocytes. Leukemia. 2012;26(9):1908-75. DOI: $10.1038 /$ leu.2012.120 